\title{
Technological schemes of coal extraction in closed mines with the use of backhoes
}

\author{
Vladimir Makarov ${ }^{1, *}$, Valery Kolesnikov ${ }^{2}$, and Dawid Szurgacz ${ }^{3}$ \\ ${ }^{1}$ Stroyservice CJSC, 650055 Kemerovo, 121 Kuznetsky Avenue, Russian Federation \\ ${ }^{2}$ T.F. Gorbachev Kuzbass State Technical University, Open Pit Mining Department, \\ 650000 Kemerovo, 28 Vesennyaya st., Russian Federation \\ ${ }^{3}$ Center of Hydraulics DOH Ltd, ul. Konstytucji 147, 41-906 Bytom, Poland
}

\begin{abstract}
At the present time on the fields of operating and closed-down mines there are sections of open-pit operations. However, the adopted technology does not meet environmental requirements, there are no scientific recommendations on the technology of open-pit mining in hazardous areas of mine fields, there is no substantiation of the boundary contours of open-pit mining. A characteristic feature of depleted mine fields is the disturbed rock mass and the lack of concentrated coal reserves within their boundaries. In fact, coal reserves are represented in the form of fragmentary volumes of safety pillars and substandard reserves in places of geological disturbances. Limitation of mine fields in terms of various infrastructure objects imposes special requirements for mining operations. In these conditions it is not possible to apply the classic mining systems and technologies. This predetermines the necessity to develop new technological solutions. Therefore, scientific research on justification of technology for extraction of remaining reserves of coal after underground development of inclined and steep-sloping coal deposits with simultaneous reclamation of disturbed lands is actual.
\end{abstract}

\section{Introduction}

Analysis of the open-pit mining technology of some areas of the closed underground mines of the Prokopyevsk-Kiselevsk coal district (part of Kuzbass) showed that a longitudinal deepening system of open-pit mining is mainly used here. The specific feature of the technology is the intersection of zones of coal seams depleted by the underground mining method [1-5].

The disadvantages of the applied technology are the impossibility of carrying out reclamation works after the advance of the front of mining works, the possibility of effective extraction of small coal seams is excluded, the necessary to place overburden rocks on external dumps [6-12]. Moreover, these disadvantages have a negative impact on environmental safety.

To remove the disadvantages of it technology and to ensure environmental safety, technologies of partial and total environmental rehabilitation of abandoned mines fields are

\footnotetext{
* Corresponding author: v.makarov@,stroyservice.com
} 
applied. To realize the proposed technology, schemes of preparatory mine workings during the rehabilitation of mine fields by open-cut method have been developed [13-17].

\section{Materials}

In case of transverse movement of the excavation front, the coal seams get into excavator strips along the whole height of the working zone mainly at a certain angle to the line of movement of the excavation front. Excavation of coal seams in this case is carried out according to the outpacing technology relative to the main volume of overburden. Initially along the entire length of the transverse front of work or part of it the host rocks are loosened within the boundaries of the transverse excavator strip with the help of drilling and blasting operations. After that from the hanging wall the rock is excavated with the following excavation of coal seams with a hydraulic excavator of backhoe type with loading in a dump truck.

The remaining rock on the working site of a bench is removed with a dragline to the inner waste dump.

It is also possible that in the case of the outpacing technology, only the rocks from the hanging wall are drilled and blasted in the boundaries that ensure the opening of strata to the height of the mined-out subbench.

Then after removal of rocks from the hanging side of the coal seam it is excavated with a hydraulic backhoe excavator.

After excavation of coal seams along the entire length of the excavator front, the remaining unexploded rocks are drilled and blasted followed by their movement to the inner dump by a dragline.

\section{Results}

Developed technological schemes of coal seams excavation reflect the most typical conditions of seams entering the excavator strip.

\section{Scheme 1}

The scheme provides for preliminary explosive breaking of rocks in the boundaries of the excavator strip from the hanging side of the coal seam.

The scheme is designed for excavation of disturbed coal pillars with dip angle $\alpha$ over $50^{\circ}$. Coal pillar is excavated in two layers. Firstly, the upper layer is excavated to the depth that provides stability of coal face. For this purpose, the backhoe first moves along the seam from the hanging side along the rock breakage, and performs excavation with the outcrop of the hanging side of the seam to the depth of the layer with the unloading of rock on the breakage of blasted rock (Fig. 1).

In the second path the backhoe is positioned on the lying side of the layer and excavates it with the lower scooping to the layer depth with loading in a dump truck located at the excavator standing level. The bottom layer is excavated using the same technology.

In case of hollows in the zone of underground layer excavation the backhoe, when excavating from the hanging side of the coal face, places the rock in it hollows.

The scheme corresponds to the situation when the seam (pillar) is fully located within the area of excavator strip, and beyond it the seam is mined by underground method. But according to this technological scheme it is also possible to excavate pillars at other variants of pillar location on the working site of a bench. 
a)

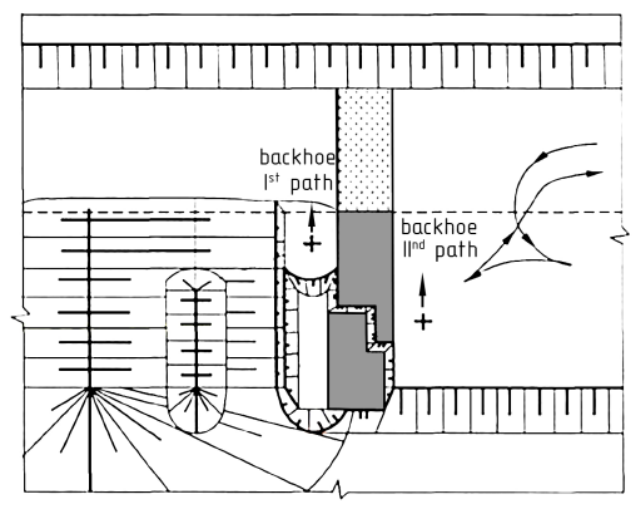

b)

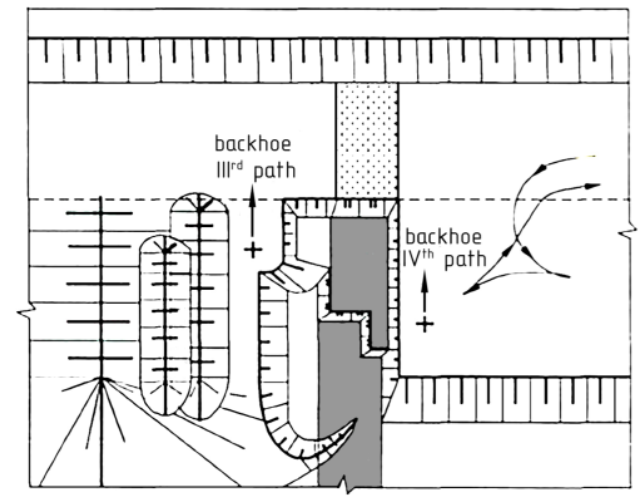

Fig. 1. Technological scheme of outpacing excavation of coal pillar by backhoe on the upper horizon in the undermining zone at $\alpha>50^{\circ}: a$ - excavation of the upper layer of the seam (pillar); $b$ - excavation of the lower layer of the seam (pillar).

\section{Scheme 2.}

The technological scheme is designed for excavation of the remaining coal reserves in the pillars, slightly disturbed by underground mining operations.

The rock mass from the hanging side of the seam is loosened by drilling and blasting according to the method developed at T.F. Gorbachev Kuzbass State Technical University, excluding the destruction of the coal seam (Fig. 2).

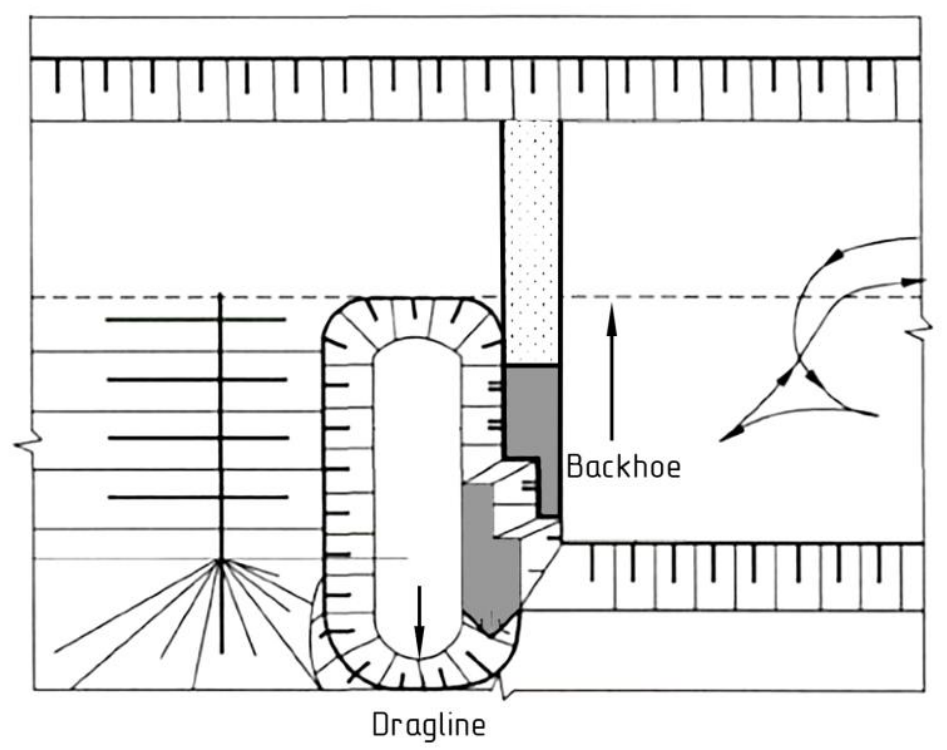

Fig. 2. Technological scheme of excavation of coal seam (pillar) weakly disturbed by underground works with advanced removal of exploded rocks by draglines in the mode of scraping from the hanging side of the seam.

After that, using the dragline installed on the intermediate horizon of the internal dump, overburden is excavated from the hanging side of the bed to the full height of the pad in the mode of scraping with the movement of rocks in the excavation zone with the subsequent 
stacking in the inner dump. Thus, the coal seam roof, partially located within the excavator strip, is uncovered.

Then the backhoe is installed on the lying side of the coal seam, which cleans the end part of the seam at the slope of the bench and excavates the seam with the lower digging, loading it into a dump truck, located at the level of the excavator standing.

\section{Conclusion}

The developed schemes of preliminary mine workings during the rehabilitation of mine fields by open-pit method allow to realize the technology of outpacing excavation of coal pillars, left by underground works.

In case of transverse movement of the excavation front, coal seams get into excavator strips along the whole height of the working zone mainly at a certain angle to the line of front movement of the mining works. Excavation of coal seams in this case is carried out by outpacing technology relative to the main volume of overburden rocks.

\section{References}

1. D. Szurgacz, R. Diederichs, M. Brzózka, Journal of Mining and Geotechnical Engineering, 3:10, 4 (2020)

2. D. Mettinge, G. Lumeley, Coal age, 9, 64 (1999)

3. M. Tyulenev, S. Zhironkin, E. Tyuleneva, A. Abay, S. Anyona, M. Hellmer, Coal International, 265:3, 30 (2017)

4. I. Vukotic, V. Kecojevic, W. Zhang, Q. Cai, S. Chen, Int J Mining Sci Tech, 23:6, 901 (2013)

5. A. I. Arsent'ev Vskrytie i sistemy razrabotki kar'ernyh polej (Moskva, Nedra, 1981)

6. M. Andrejiova, A. Grincova, D. Marasova, P. Grendel, Acta Montanistica Slovaca, 20:1 26 (2015)

7. V. F. Baranov, P. I. Tomakov, B. C. Dergachyov, Ugol', 12, 9 (1959)

8. M. Tyulenev, Yu. Lesin, E. Tyuleneva, E. Murko, E3S Web of Conf., 15, 02003 (2017)

9. V. S. Vagorovskij, Ugol', 6, 25 (1979)

10. M. Vaněk, G.F. Valverde, I. Černý, V. Hudeček, Acta Montanistica Slovaca, 25:2, 170 (2020)

11. M. A. Tyulenev, S. O. Markov, M. A. Gasanov, S. A. Zhironkin, Geotech Geol Eng, 36:5, 2789 (2018)

12. E. I. Vasil'ev, Yu. I. Zvyagincev, IGD SO AN SSSR, 47 (1972)

13. S. Markov, V. Martyanov, E. Preis, A. Abay, E3S Web of Conf., 21, 01021 (2017)

14. A. V. Vaneev, J Mining Geotech Eng, 2, 13 (2018)

15. A. V. Demchenko, V. A. Ermolaev, S. M. Fedotenko, Ugol', 1, 21, (1997)

16. S. Markov, M. Tyulenev, O. Litvin, E. Tyuleneva, E3S Web of Conf., 15, 01011, (2017)

17. S.M. Miliy, Journal of Mining and Geotechnical Engineering, 1:8, 45, (2020) 